\title{
Tree Stock, Structure and Use of Common Woody Species of a Town Neighboring Forest Reserve in Tanzania: Implication for Managing Carbon Accumulation
}

\author{
Robert Modest Byamungu, Sayuni B. Mariki and \\ Nickson Peter Mkiramweni \\ Additional information is available at the end of the chapter
}

http://dx.doi.org/10.5772/intechopen.76003

\begin{abstract}
Town neighboring forests in the tropics suffer high human pressure owing to unregulated harvest to supply domestic energy and equipment. Although this causes considerable source of income among communities, it poses significant deforestation, thus, jeopardizing carbon accumulation potentials of most of the forests. This study therefore assessed the stock, structure and use of common woody species in a town neighboring forest reserve to elucidate the reserve's carbon accumulation potential amid pressures from surrounding communities. It was found out that the structure of the forest had been altered following unregulated tree harvest. There were selective harvesting and removal of valued timber trees, and key species that otherwise are responsible in regulating the ecosystem functioning of the reserve. It was apparent that the unregulated harvest is likely to jeopardize the ecosystem functioning and carbon accumulation potential of the reserve. Thus, to manage the reserve sustainably, awareness education on forest biodiversity conservation among surrounding local communities is recommended. We also recommend exploration of the reserve for ecotourism potentials. This might stimulate ecotourism activities in the area and provide an alternative source of income among the local population. This would add value and sense of ownership and stimulate selfmobilization for protection of the reserve.
\end{abstract}

Keywords: miombo, savanna, harvest, exploitation, community, tropics, Africa 


\section{Introduction}

The ecosystems of tropical natural forests are undergoing rapid destruction due to increasing of many factors including anthropogenic activities, natural catastrophes and climate change. Understanding in detail the drivers of such destruction and implied effects on carbon accumulation is of vital importance for conservation [1]. The majority of the forest ecosystems especially in the tropic are never been stable following anthropogenic pressures, climatic, and geo-morphological influences [2]. Overall, the threats facing the tropical forests due to anthropogenic activities are habitat modification and destruction [3] of which burning and harvesting are the most pressing [3-9]. The reasons behind burning are many including attainment of higher visibility to evade wild carnivores, to find prey among hunters and initiation of off-season re-growth of perennial fodders $[5,6]$. Harvesting, on the other hand, comes in many forms to fulfill needs such as firewood, building materials, domestic items (e.g., mortar, bow, arrow handle, spear handle), fencing materials, among others. While these forms of use of forest products cause significant source of income for many small scale farmers in developing countries, they pose significant deforestation [10]. For example, in the 1990s, there were approximately 40 million people living in Africa's miombo woodlands-all with an additional 15 million urban residents depending on the woodlands for domestic fuel-especially charcoal [11]. Moreover, the building materials and fuel energy are needed in high supply particularly for forests neighboring residential areas [1, 10]. In Kenya, for instance, some tree species such as Brachylaena huillensis and Dalbergia melanoxylon are highly sought and have been depleted in forests near towns [12]. In Tanzania, tree species such as Pterocarpus angolensis, Milicia excelsa, Afzelia quanzensis, Khaya anthotheca and D. melanoxylon are categorized as protected trees due to overexploitation and harvesting them even on private land requires the government authorization [13, 14].

Some studies indicate that valued timber trees such as $P$. angolensis suffers high human pressure and are highly sought throughout south-central Africa [15, 16], such that the stock in most places has been depleted to vulnerable numbers [17, 18], and the structure has been damaged beyond repair in the near future in some reserves [19]. In Msagania Forest Reserve for example, Schwartz et al. [18] reported that loggers have reduced the population density of $P$. angolensis from 11.4 to 3.7 trees/ha, whereby, trees are left standing only if they are not of harvestable size yet. This kind of selective use has a profound impact on tree stock and structure and can jeopardizes the forests carbon accumulation potential [20] as well as the general biodiversity [21, 22]. The fact that most important sites and habitats in Tanzania are not included in a reserved areas system, and most of those under the reserved areas system are not well protected [1, 23], the forests are likely to continue experiencing unregulated exploitation from surrounding communities [1, 23, 24], thus jeopardizing their carbon accumulation potential.

This study therefore aimed at assessing the stock, structure and use of common woody species in a town neighboring forest reserve to elucidate its carbon accumulation potential and put forward management recommendations. The forest, hereby referred to as Ndege Forest Reserve (NFR) is a small reserve located about $10 \mathrm{~km}$ north of Morogoro Municipality, Tanzania (Figure 1). The surrounding local communities have depleted its biological and ecological resources to unprecedented level. There is widespread tree felling, encroachment and bushfires [14]. The northwest slope of the reserve is already completely deforested and its 


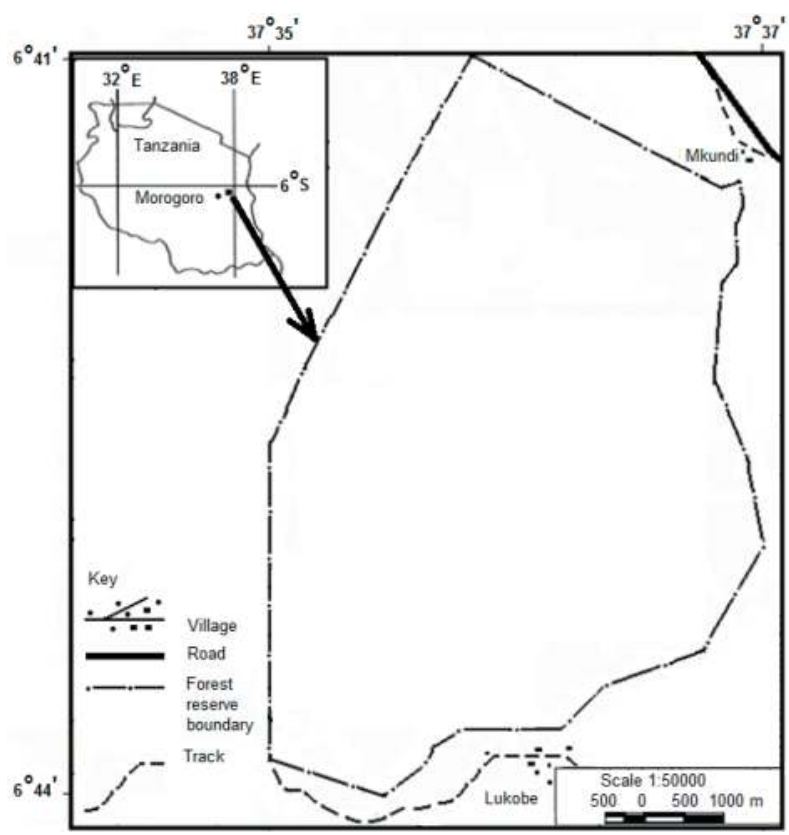

Figure 1. Map showing location of the study area: modified after national tree seed programme in Tanzania, NTSP [30].

entire valued tree has been wiped out [25]. However, there is lack of information on natural stands of different plant species in this reserve. The fact that information on threats facing trees is usually scanty and anecdote, assessment of tree stock, structure and human use for the NFR may shade light on our knowledge on carbon accumulation potential of the reserves neighboring towns in tropical Africa.

\section{Materials and methods}

This study was conducted in Ndege Forest Reserve (NFR). This reserve is found between $6^{\circ} 41^{\prime}$ to $6^{\circ} 44^{\prime} \mathrm{S}$ and $37^{\circ} 35^{\prime}$ to $37^{\circ} 37^{\prime} \mathrm{E}[25,26]$. It is a small reserve covering an area of about $36.14 \mathrm{~km}^{2}$ and is located about $10 \mathrm{~km}$ north of Morogoro Municipality, Tanzania (Figure 1). The rainfall is estimated at $850 \mathrm{~mm} /$ year and the temperatures range from $20-25^{\circ} \mathrm{C}$ [25]. The vegetation of the area is mainly woodlands $[25,26]$. The dominant tree species of the reserve are Brachystegia microphylla, Brachystegia boehmii and Julbernardia globiflora. Some other trees include Albizia harveyi, Brachystegia spiciformis, Sterculia africana, Sterculia quinqueloba and Xeroderris stuhlmannii. Important timber species in the reserve are Brachystegia spp., $P$. angolensis and Afzelia quanzensis [26].

During data gathering, we sampled 50 sites in which we took vegetation measurements and indices of tree use. The detailed study design and vegetation sampling procedure is explained in Modest et al. [14]. In brief, we measured diameter at breast height (dbh), crown 
diameter and height of trees and counted saplings $(\mathrm{dbh} 1 \leq 10 \mathrm{~cm})$ and trees $(\mathrm{dbh}>10 \mathrm{~cm})$. The stump diameters were as well measured. This data was collected within 50 quadrats measuring 20 by $20 \mathrm{~m}$ spread randomly in the study area. Furthermore, additional 50 quadrats measuring 5 by $5 \mathrm{~m}$ were established within the 20 by $20 \mathrm{~m}$ quadrats for sampling seedlings which were regarded as small trees with $\mathrm{dbh}<1 \mathrm{~cm}[27,28]$. We also recorded the global positioning system (GPS) data for each quadrat for use in determining the distribution of valued timber tree species in the reserve.

We analyzed the data, first by determining the floristic composition of all woody species through preparing a checklist; then, using previously published literature, we assigned the tree species in their respective families and defined their habit. Second, from the checklist we determined the common woody species using the Important Value Index (IVI) criteria following Kent and Coker [29], as follows:

$$
\begin{aligned}
& \text { IVI }=\text { relative dominance }+ \text { relative frequency }+ \text { relative density } \\
& \text { where } \\
& \text { Relative dominance }=(\text { Sum of basal area of the ith species } / \text { total basal area } \\
& \text { of all species }) \times 100 .
\end{aligned}
$$

Relative density $=($ Number of stems $/$ ha of the ith species $/$ total number of stems/ha of all species) $\times 100$.

Relative frequency $=($ Frequency of the ith species $/$ total frequency of all species $) \times 100$.

Here, the first 10 species with the highest IVIs were picked as common species and the rest of the discussion in this chapter refers to them.

We proceeded in assessing the stock, structure and use of common woody species by determining their population structure, conservation priority, level of exploitation and spatial distribution. The population structure was assed based on tree population density, tree dbh, density distribution of seedlings, saplings and mature trees and canopy diameter as well as canopy area. The population density on the other hand was calculated as number of individual plants/ha [29, 31, 32]. The tree dbh were categorized into 10 classes from class $1 \mathrm{dbh} 0-4.9 \mathrm{~cm}$, class 2 dbh 5-9.9 cm, class 3 dbh 10-14.9 cm, class 4 dbh 15-19.9 cm, class 5 dbh 20-24.9 cm, class 6 dbh 25-29.9 cm, class $7 \mathrm{dbh} 30-34.9 \mathrm{~cm}$, class 8 dbh 35-39.9 cm, class $9 \mathrm{dbh} 40-44.9 \mathrm{~cm}$ and class $10 \mathrm{dbh}$ above $45 \mathrm{~cm}[33,34]$. The dbh were also grouped into three categories following Jones [35] to determine the density of seedlings, saplings and mature trees as follows: seedlings, individuals with $\mathrm{dbh}<1 \mathrm{~cm}$ saplings, individual with $\mathrm{dbh} 1 \leq 10 \mathrm{~cm}$ and trees, individual with $\mathrm{dbh}>10 \mathrm{~cm}$ 
Moreover, the canopy diameters were standardized and presented as mean canopy diameter \pm SE, while the canopy area (CA) was calculated following Cunningham [33] as shown below:

$$
\mathrm{CA}=\mathrm{W} 1 / 2 \times \mathrm{W} 2 / 2
$$

where $\mathrm{W} 1$ = widest canopy diameter and W2 = perpendicular diameter to the widest diameter.

The conservation priority for each of the 10 common woody species was determined using the IVI classes and the regeneration status based on density of seedlings and saplings following Shibru and Balcha [36]. For this case, the IVIs were categorized into five classes:

Class $5=$ IVI $(<1)$

Class 4 = IVI (1-10)

Class 3 = IVI (10.1-20)

Class 2 = IVI (20.1-30) and

Class $1=$ IVI $(>30)$

The seedlings and saplings on the other hand were grouped into three classes:

Class 1: species with 0 individual seedling and saplings ha-1

Class 2: species with $0>50$ individual seedlings and saplings ha-1

Class 3: species with $<50$ individual seedlings and saplings ha-1

To assess the level of exploitation of the trees, we determined the basal area of the stumps. First, the stump diameters were converted into dbh using this linear regression equation presented in Luoga et al. [37]; $\mathrm{dbh}=-3.17+0.961 \mathrm{SD}$, where $\mathrm{SD}=$ stump diameter. Then, the resulting dbh were used to calculate the basal area following Martin [38] as follows; BA $=\pi(\mathrm{dbh} / 2)^{2}$, where dbh is diameter at breast height. Finally, we assessed the distribution of the highly valued timber species $P$. angolensis using the ArcView computer software version 3.2.

\section{Results and discussion}

\subsection{Floristic composition and population structure of the common woody species}

A total of 102 woody species were recorded in the reserve and were represented by 30 families as presented in Table 1. The most dominant family was Fabaceae with 31 species, whereas several other families were represented by only one species. Of the 102 woody species recorded, 78 were trees while 24 were shrubs. The first 10 common woody species determined using the IVI classification procedure were Acacia nilotica, Brachystegia boehmii, Brachystegia microphylla Combretum molle, Dalbergia boehmii, Diplorhynchus condylocarpon, Julbernardia globiflora, Lannea welwitschii, Pteleopsis myrtifolia and Pterocarpus angolensis. The 


\begin{tabular}{|c|c|c|c|c|}
\hline SN & Species name & Family & Habit & \\
\hline & & & Shrub & Tree \\
\hline 1 & Ozoroa insignis Del. & Anacardiaceae & * & \\
\hline 2 & Ozoroa reticulata (Baker F.) R. Fern. \& A. Fern. & * & * & \\
\hline 3 & Lannea schimperi (A. Rich.) Engl. & * & & * \\
\hline 4 & Lannea welwitschii (Hiern) Engl. & * & & * \\
\hline 5 & Sclerocarya birrea (A. Rich.) Hochst. & * & & * \\
\hline 6 & Sorindeia madagascariensis Baill & * & & * \\
\hline 7 & Annona senegalensis Pers & Annonaceae & & * \\
\hline 8 & Steganotaenia araliacea Hostchst. & Apiaceae & * & \\
\hline 9 & Diplorhynchus condylocarpon (Muell-Arg.) Pichon & Apocynaceae & & * \\
\hline 10 & Kigelia africana (Lam) Benth. & Bignoniaceae & & * \\
\hline 11 & Markhamia obtusifolia (Baker) Sparague & * & & * \\
\hline 12 & Stereospermum kunthianum Cham. & * & & * \\
\hline 13 & Bombax rhodognaphalon $\mathrm{K}$. Schum. & Bombacaceae & & * \\
\hline 14 & Ehretia amoena Klotzsch & Boraginaceae & & * \\
\hline 15 & Commiphora africana (A. Rich.) Engl. & Burseraceae & * & \\
\hline 16 & Boscia salicifolia Oliv. & Capparidaceae & * & \\
\hline 17 & Maerua triphylla A.Rich & * & & * \\
\hline 18 & Maytenus senegalensis (Lam.) Excell & Celastraceae & & * \\
\hline 19 & Parinari excelsa Sabine & Chrysobalanaceae & & * \\
\hline 20 & Garcinia huillensis Welw & Clusiaceae & & * \\
\hline 21 & Combretum adenogonium Steud. ex A. Rich & Combretaceae & & * \\
\hline 22 & Combretum collinum Fresen. & * & & * \\
\hline 23 & Combretum molle R.Br. ex G. Don & * & & * \\
\hline 24 & Combretum padoides Engl. \& Diels & * & & * \\
\hline 25 & Combretum zeyheri Sond. & * & & * \\
\hline 26 & Pteleopsis myrtifolia Engl. \& Diels & * & & * \\
\hline 27 & Terminalia sericea Burch. ex DC & * & & * \\
\hline 28 & Diospyros consolatae Chiov. & Ebenaceae & * & \\
\hline 29 & Diospyros zombensis (B.L. Burt) F. White & * & * & \\
\hline 30 & Diospyros kirkii Hiern & * & & * \\
\hline 31 & Diospyros mespiliformis Hochst. ex A. DC & * & & * \\
\hline 32 & Drypetes gerrardii Hutch & Euphorbiaceae & * & \\
\hline 33 & Bridelia cathartica Bertol.F. & * & & * \\
\hline 34 & Croton macrostachyus Hochst. ex Delile & * & & * \\
\hline
\end{tabular}




\begin{tabular}{|c|c|c|c|c|}
\hline SN & Species name & Family & Habit & \\
\hline 35 & Croton megalocarpus Hutch & * & & * \\
\hline 36 & Margaritaria discoidea (Baill.) Webster & * & & * \\
\hline 37 & Pseudolachnostylis maprouneifolia Pax & * & & * \\
\hline 38 & Spirostachys africana Sond & * & & * \\
\hline 39 & Suregada zanzibariensis Baill. & * & & * \\
\hline 40 & Acacia pentagona (Schumach.) Hook. F. & Fabaceae & * & \\
\hline 41 & Bauhinia petersiana C. Bolle & * & * & \\
\hline 42 & Cassia abbreviata Oliver & * & * & \\
\hline 43 & Dichrostachys cinerea (L.) Wight \& Arn & * & * & \\
\hline 44 & Ormocarpum kirkii S. Moore & * & * & \\
\hline 45 & Acacia goetzei Harms. & * & & * \\
\hline 46 & Acacia goetzei subsp. microphylla Brenan & * & & * \\
\hline 47 & Acacia nigrescens Oliver & * & & * \\
\hline 48 & Acacia nilotica (L.) Willd.ex Del & * & & * \\
\hline 49 & Acacia polyacantha subsp. & * & & * \\
\hline 50 & Afzelia quanzensis Welw. & * & & * \\
\hline 51 & Albizia harveyi Fourn & * & & * \\
\hline 52 & Albizia petersiana Oliver & * & & * \\
\hline 53 & Brachystegia boehmii Taub. & * & & * \\
\hline 54 & Brachystegia microphylla Harms & * & & * \\
\hline 55 & Brachystegia spiciformis Benth & * & & * \\
\hline 56 & Dalbergia boehmii Taub & * & & * \\
\hline 57 & Dalbergia melanoxylon Guill.\& Perr & * & & * \\
\hline 58 & Dalbergia nitidula Baker & * & & * \\
\hline 59 & Dalbergia obovata E. Mey. & * & & * \\
\hline 60 & Erythrina abyssinica Lam.ex DC & * & & * \\
\hline 61 & Erythrophleum africanum (Benth.) Harms & * & & * \\
\hline 62 & Julbernardia globiflora (Benth.) Troupin & * & & * \\
\hline 63 & Lonchocarpus bussei Harms & * & & * \\
\hline 64 & Millettia usaramensis Taub & * & & * \\
\hline 65 & Pterocarpus angolensis DC. & * & & * \\
\hline 66 & Pterocarpus tinctorius Welw. & * & & * \\
\hline 67 & Scorodophloeus fischeri (Taub.) J. Leon & * & & * \\
\hline 68 & Swartzia madagascariensis Desv. & * & & * \\
\hline 69 & Xeroderris stuhlmannii (Taub.) Mendoca \& Sousa & * & & * \\
\hline
\end{tabular}




\begin{tabular}{|c|c|c|c|c|}
\hline SN & Species name & Family & Habit & \\
\hline 70 & Pterocarpus rotundifolius (Sond.) Druce & * & & * \\
\hline 71 & Strychnos spinosa Lam. & Loganiaceae & & * \\
\hline 72 & Ficus bussei Mildbr.\& Burret & Moraceae & & * \\
\hline 73 & Ficus exasperata Vahl & * & & * \\
\hline 74 & Ficus sycomorus L. & * & & * \\
\hline 75 & Treculia africana Decne. ex Trecul & * & & * \\
\hline 76 & Ochna leptoclada Oliver & Ochnaceae & & * \\
\hline 77 & Ximenia americana $\mathrm{L}$. & Olacaceae & & * \\
\hline 78 & Ximenia caffra Sond. & * & & * \\
\hline 79 & Ziziphus mucronata Willd & Rhamnaceae & & * \\
\hline 80 & Crossopteryx febrifuga (G.Don) Benth. & Rubiaceae & * & \\
\hline 81 & Gardenia ternifolia Schumach. \& Thonn. & * & * & \\
\hline 82 & Pavetta crassipes K.Schum & * & * & \\
\hline 83 & Vangueria infausta Burch. & * & * & \\
\hline 84 & Catunaregam spinosa (Thumb) Tirveng. & * & & * \\
\hline 85 & Grumilea riparia $\mathrm{K}$. Schum \& K. Krause & * & & * \\
\hline 86 & Toddalia asiatica Baill. & Rutaceae & * & \\
\hline 87 & Zanthoxylum chalybeum Engl. & * & * & \\
\hline 88 & Allophyllus africanus P. Beauv. & Sapindaceae & * & \\
\hline 89 & Deinbollia borbonica Scheff. & * & * & \\
\hline 90 & Haplocoelum inopleum Radlk & * & & * \\
\hline 91 & Lecaniodiscus fraxinifolius Bak. & * & & * \\
\hline 92 & Zahna africana (Radlk.) Exell & * & & * \\
\hline 93 & Synsepalum brevipes (Baker) T.D. Penn & Sapotaceae & & * \\
\hline 94 & Harissonia abyssinica Oliv. & Simaroubaceae & * & \\
\hline 95 & Dombeya cincinnata K. Schum. ex Engl. & Sterculiaceae & & * \\
\hline 96 & Dombeya rotundifolia (Hochst.) Planch. & * & & * \\
\hline 97 & Sterculia africana (Lour.) Fiori. & * & & * \\
\hline 98 & Sterculia quinqueloba (Garcke) K. Schum & * & & * \\
\hline 99 & Grewia ectasicarpa S. Moore & Tiliaceae & * & \\
\hline 100 & Grewia bicolor Juss. & * & & * \\
\hline 101 & Heteromorpha trifoliata (Wendl.) Eckl. \& Zeyh. & Umbelliferae & * & \\
\hline 102 & Vitex payos (Lour.) Merr. & Verbenaceae & & * \\
\hline
\end{tabular}

Table 1. Checklist for the tree species recorded during field survey. Under the "Family" column, the star “*” denote that the species belongs to the family mentioned above it. The same star under the "Habit" column denote that the species is either a Shrub if the star is under the "Shrub" column, otherwise the species is a Tree. 


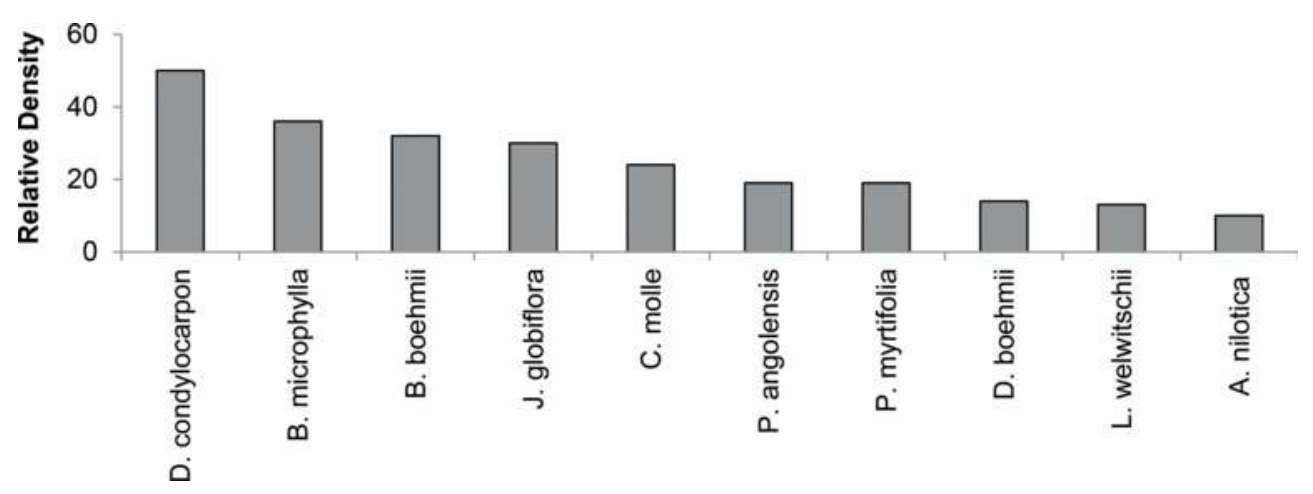

Figure 2. Relative density of the common woody species in NFR.

relative density of these common woody species for stems with $\mathrm{dbh}>4 \mathrm{~cm}$ is presented in Figure 2, whereby, D. condylocarpon had the highest relative density of $50 \mathrm{stem} / \mathrm{ha}$, while L. welwitschii had the least density that is, 13 stem/ha.

The population structure of the common woody species in NFR was assessed based on dbh class size distribution, mean crown diameter and area, and density distribution of seedlings, saplings and mature trees. The dbhs of the common woody species recorded during the study are presented in Figure 3. All the 10 representative woody species had more individuals in their first classes with an abrupt drop beginning in the following class indicating the characteristic inversed J-shapes. However, except for C. molle of which its graph had a smooth inversed J-shape, the graphs for the rest of the species seemed interrupted. This is an indication of selective removal of individuals, especially those at pole size stages and the mature ones. The Morogoro region in which NFR is located has a history of human exploitation of tree species. For example, Wells and Wall [39], reported that, between 1970 and 1980 Morogoro Region was the source of much of the hardwood timber going to the Dar es Salaam market, but from early 1990s, the Morogoro region was exhausted of valued timber species such as $P$. angolensis and the production shifted to Tabora region, and even further west to Rukwa Region by late 1990s. Therefore, this denotes that, NFR being in Morogoro region, its quality timber trees has long been extracted, which is also evidenced by small dbhs in almost all the common tree species Figure 3. Moreover, the trend in dbh classification of the 10 common woody species (Figure 3) indicates that the graphs of some species such as B. microphylla are almost flat for individuals from the sapling stage. This is not a health state for the NFR since it is evident that trees are harvested in all stages from sapling to mature trees. Newton [40] pointed out that, when there is a very few trees recorded in lower dbh classes, extracting of large sized trees is detrimental to the future populations. Therefore, if unsustainable harvest continues in NFR, it is likely that the knock-off effect of the forest valuable trees will occur within a short span of time.

Figure 4 shows that of the common woody species B. microphylla had the biggest mean canopy diameter while that of $C$. molle was the smallest. Moreover, the mean canopy area was also the biggest for B. microphylla and the smallest for C. molle as shown in Table 2. The bigger crown diameter and area of $B$. microphylla as well as its higher density are indication that the species is potential especially in influencing the ecosystem functioning of the reserve. Thus, B. microphylla can be regarded as a foundation species for the NFR. By definition, a 

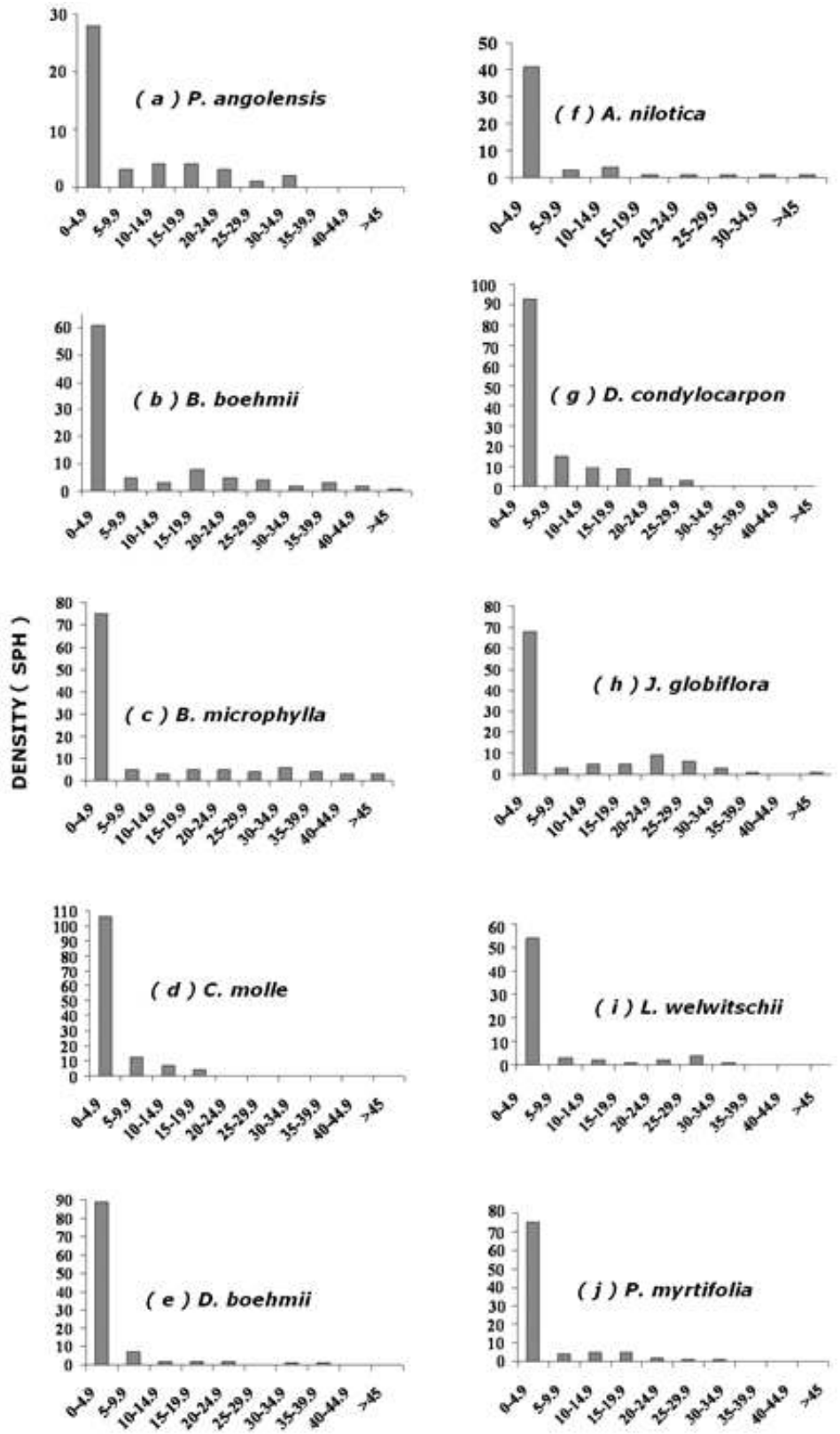

DBH CLASSES ( CM)

Figure 3. DBH class distribution of the common woody species recorded in NFR. 


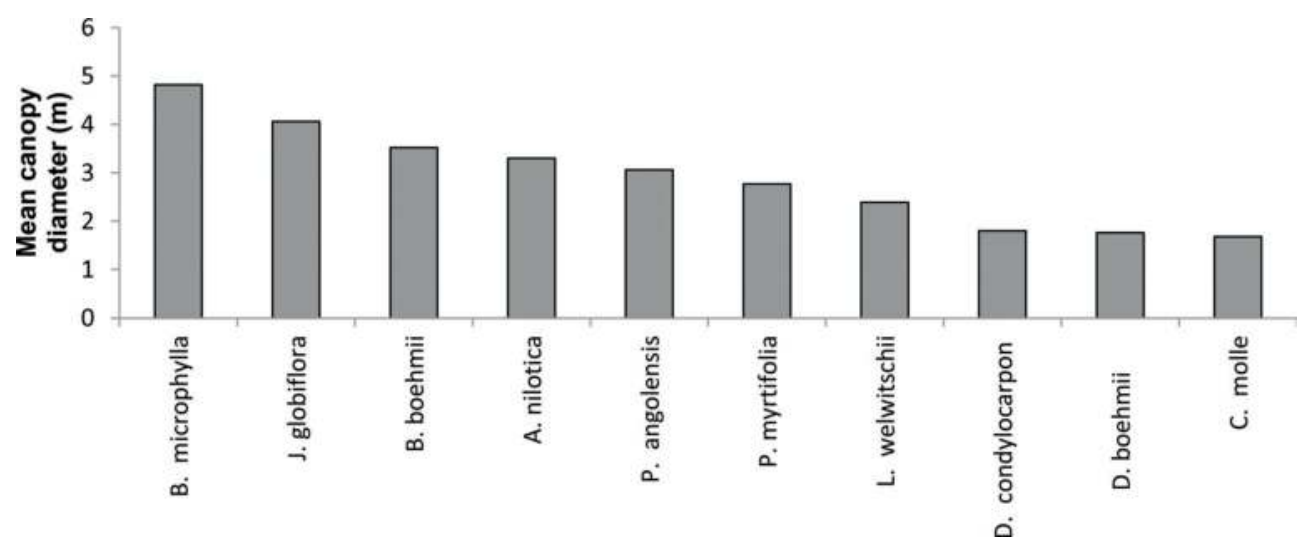

Figure 4. Mean canopy diameter of the common woody species.

\begin{tabular}{lllll}
\hline Scientific name & $\begin{array}{l}\text { Mean canopy area/ } \\
\text { ha }\left(\mathbf{m}^{2}\right)\end{array}$ & $\begin{array}{l}\text { Std. error of the mean } \\
\text { (SEM) }\end{array}$ & $\begin{array}{l}\text { Lower 95\% conf. } \\
\text { limit }\end{array}$ & $\begin{array}{l}\text { Upper 95\% conf. } \\
\text { limit }\end{array}$ \\
\hline B. microphylla & 11.55 & 1.46 & 8.64 & 14.46 \\
J. globiflora & 8.19 & 0.94 & 6.31 & 10.08 \\
B. boehmii & 6.26 & 0.79 & 4.46 & 7.84 \\
A. nilotica & 5.44 & 0.94 & 0.40 & 13.74 \\
P. angolensis & 4.70 & 0.82 & 3.05 & 6.35 \\
P. myrtifolia & 3.42 & 0.04 & 2.42 & 4.37 \\
L. welwitschii & 3.40 & 0.89 & 01.58 & 5.21 \\
D. boehmii & 1.85 & 0.53 & 0.78 & 2.63 \\
D. condylocarpon & 1.51 & 0.14 & 1.23 & 1.79 \\
C. molle & 1.37 & 0.17 & 1.04 & 1.72 \\
\hline
\end{tabular}

Table 2. Mean canopy area/ha $\left(\mathrm{m}^{2}\right)$ of the common woody species recorded in NFR.

foundation species is "a single species that defines much of the structure of a community by creating locally stable conditions for other species and by modulating and stabilizing fundamental ecosystem processes" [41, 42]. These kinds of species with greater influence on ecosystem usually possess greater repercussions on ecosystem functioning in case they disappear [43]. Therefore, for NFR B. microphylla can be regarded as a candidate foundation species, and in case it disappears there could be far reaching consequences [43]. Probably the species we see today in NFR especially the shade tolerant ones are a masterpiece of B. microphylla. Thus, if $B$. microphylla vanishes from NFR the species composition is likely to change with cascading effects on carbon accumulation potential of the reserve. 
The classification of stems into seedlings, saplings and mature trees showed the least number of seedlings/ha for the highly valued timber species $P$. angolensis Figure 5 . The 24 seedlings/ha of $P$. angolensis were far less compared to that of $C$. mole and $D$. condylocarpon (88/ha) respectively. This could be an indication that there are difficulties in seedling germination in NFR for this species. Probably fires, damages from tree felling activities and rolling logs, or all of these combined are hampering the regeneration of the species. Other common woody species namely B. boehmii, B. microphylla, J. globiflora and P. myrtifolia had a bit higher number of seedlings but the saplings seemed to suffer a high mortality. This could be an indication that the saplings are removed to cater for different purposes such as house construction or instrument making [10].

\subsection{Tree conservation priority}

The tree conservation priority was assessed based on IVI classes and regeneration status (Table 3). Categorization of the common woody species into conservation priority classes based on IVI criteria placed L. welwitschii, D. boehmii, P. angolensis and A. nilotica in class 4 . This means that these species have insufficient stock and are recommended for conservation priority, for example, Zegeye et al. [44], Kacholi [45]. The IVI criterion is used in determining the conservation priority of species whereby those with low IVI values are considered of main concern for conservation [44]. Therefore, the management of NFR should place special consideration in protecting A. nilotica, D. boehmii, L. welwitschii and P. angolensis against anthropogenic pressures for their persistence. On the other hand, the remainder of the common woody species recorded in NFR, that is, J. globiflora, B. boehmii, D. condylocarpon, C. molle, P. myrtifolia and B. microphylla are of less conservation concern since they fall under a higher IVI class value. However, the management of NFR is not advised to relax as protection of every single species in the reserve is paramount. As pointed out earlier, B. microphylla has been categorized by this study as a foundation species, thus, despite the fact that this species appears common, it still deserves special consideration for protection in respect of its ecological implication in case it disappears.

Moreover, classification of the 10 common woody species into regeneration status placed the highly valued timber species $P$. angolensis in class 2 denoting that the species had insufficient number of seedlings and saplings (Table 4). This suggests that either the species recruitment is insufficient or the seedlings and perhaps the saplings suffer high mortality before making it to maturity, the phenomena which are likely to jeopardize its long-term persistence in the reserve. As pointed out earlier, $P$. angolensis had the least number of seedlings observed among the 10 common woody species and this is attributed to a collective number of factors including disturbances brought about by tree felling activities, or fires. Omeja et al. [34] claims that human disturbance influence seed dispersal mechanisms, fruiting, germination and regeneration of tree species. Thus, disturbance by activities involved during charcoal burning (see Plate $\mathbf{1} \mathbf{a}$ and $\mathbf{b}$ ) perhaps contributes in killing young seedlings as logging was observed almost everywhere in the reserve especially on lower altitudes. Similarly, van Daalen [46], pointed out that very high intense fire reduces the viability of seeds of $P$. angolensis limiting their germination potential. Thus, the intense fires that the NFR faces (Personal Communication) could be killing more seeds of $P$. angolensis, allowing only a few to germinate. 

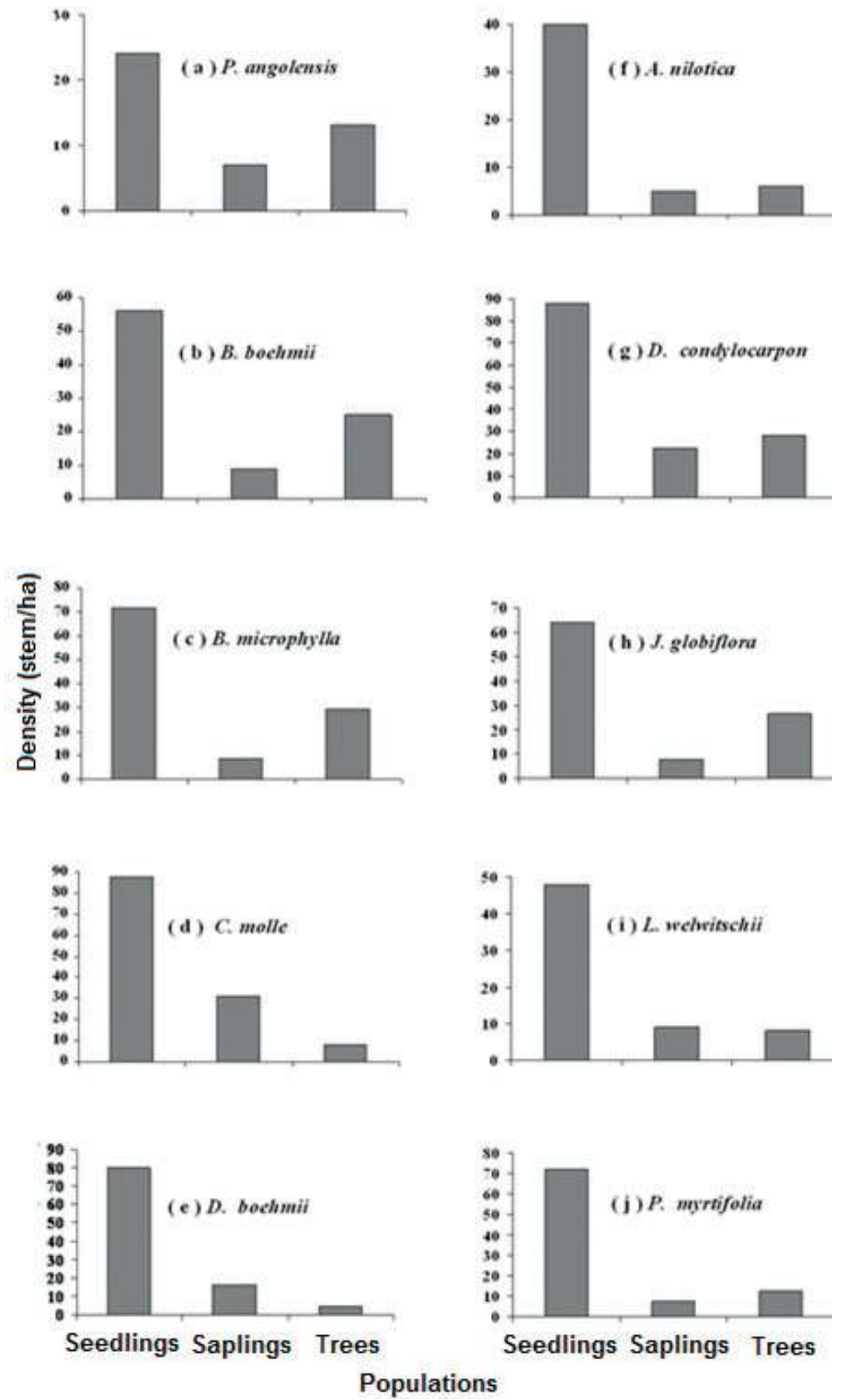

Figure 5. The population of seedlings, saplings and mature trees of the common woody species recorded in NFR. 


\begin{tabular}{lll}
\hline IVI priority classes & IVI value class & Species \\
\hline 5 & $<1$ & - \\
4 & $1-10$ & L. welwitschii \\
& D. boehmii \\
& P. angolensis \\
& A. nilotica \\
3 & $10.1-20$ & J. globiflora \\
& & B. boehmii \\
& D. condylocarpon \\
& & C. molle \\
& & P. myrtifolia \\
1 & & B. microphylla \\
& $20.1-30$ & - \\
\hline
\end{tabular}

Table 3. IVI priority classes for the 10 common species recorded in NFR.

\begin{tabular}{lll}
\hline Class 1 & Class 2 & Class 3 \\
\hline 0 individuals ha $^{-1}$ & $0>50$ Individuals ha $^{-1}$ & $<50$ Individuals ha $^{-1}$ \\
& P. angolensis & B. microphylla \\
& D. condylocarpon \\
& J. globiflora \\
& B. boehmii \\
& D. boehmii \\
& A. nilotica \\
& P. myrtifolia \\
& C. molle \\
& L. welwitschii \\
\hline
\end{tabular}

Table 4. Regeneration status of the 10 common woody species based on individual seedlings and saplings/ha.

\subsection{Exploitation and spatial distribution of the common woody species}

Harvesting rate of the common woody species was evaluated based on basal area/ha of the cut trees. During this study, some stumps could not be identified simply because most of them had already lost identification evidences such as barks and had no sprouts. Of the 10 common woody species, stumps were recorded for B. microphylla, C. molle, J. globiflora, P. angolensis and $P$. myrtifolia (Table 5). From this perspective, the total basal area for the harvested species seemed to be small $(0.32 \mathrm{~m} / \mathrm{ha})$. Of the common woody species found harvested, J. globiflora seemed to be the highly preferred species accounting for $0.14 \mathrm{~m}^{2} /$ ha followed by $P$. angolensis with $0.10 \mathrm{~m}^{2} /$ ha, while $B$. microphylla was the least harvested. The fact that this study has 


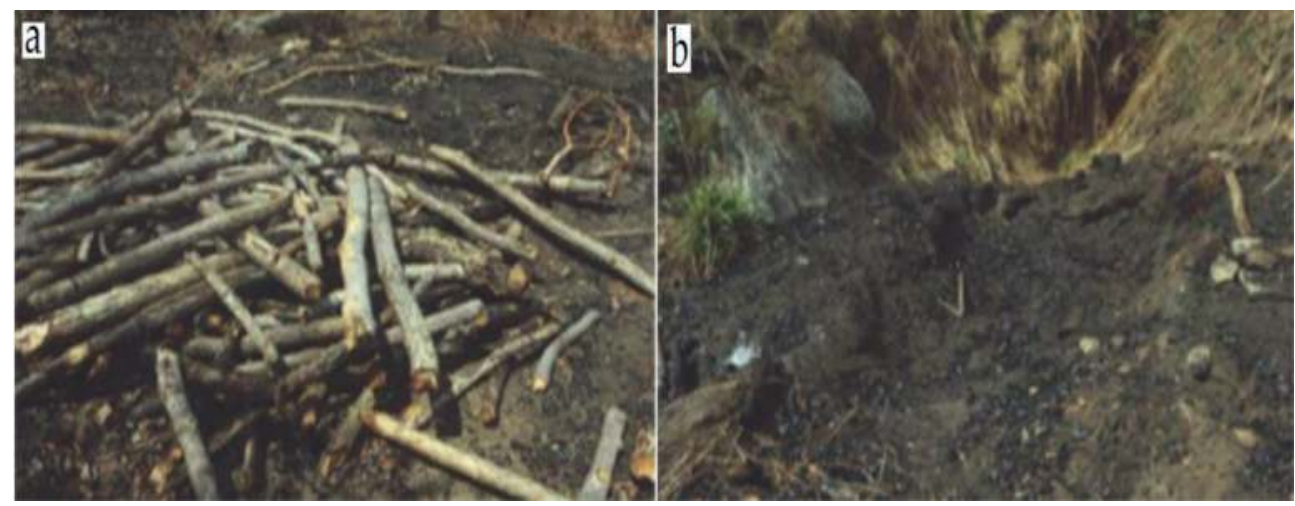

Plate 1. (a) Pieces of wood found cut for charcoal burning in NFR, (b) the kiln previously used for charcoal burning.

\begin{tabular}{llll}
\hline Scientific name & Basal area/ha $\left(\mathbf{m}^{2}\right)$ & Percentage & Rank \\
\hline J. globiflora & 0.14 & 43.34 & 1 \\
P. angolensis & 0.10 & 32.00 & 2 \\
C. molle & 0.03 & 10.70 & 3 \\
P. myrtifolia & 0.03 & 8.41 & 4 \\
B. microphylla & 0.01 & 4.54 & 5 \\
\hline
\end{tabular}

Table 5. Basal area/ha of the common woody species found harvested in NFR.

considered B. microphylla as a foundation species following its bigger canopy area, the removal of this species though at a smaller scale triggers alarm. As pointed out earlier, this species has a high chance of influencing other species especially in suppressing shade intolerant species. Therefore, if harvest continues for B. microphylla, there is a high possibility of seeds for other species that were being suppressed to start emerging and this could change the species composition and ultimately the ecosystem functioning and carbon accumulation potential of the area. Some previous studies pointed out that increasing ground illumination through felling bigger canopy trees has many consequences including allowing colonization of new plant species and development of new communities such as grasses [9, 20], thus impairing the ecological succession and carbon accumulation potential of the affected area [20]. Therefore, exploitation of trees in NFR especially among key species needs to be monitored by the responsible authorities for stability of ecosystem processes in the reserve.

One of the important questions under the current study concerned the distribution of valued timber species in NFR. This was so in order to elucidate the probable influence of the surrounding community on the reserve's valued biological resources. To understand this, we plotted the spatial distribution of the highly valued timber species $P$. angolensis on the reserve's map as shown in Figure 6. From the map, it was apparent that quadrats into which $P$. angolensis were recorded concentrated more in the higher altitudes of the reserve to the interior. We did not 


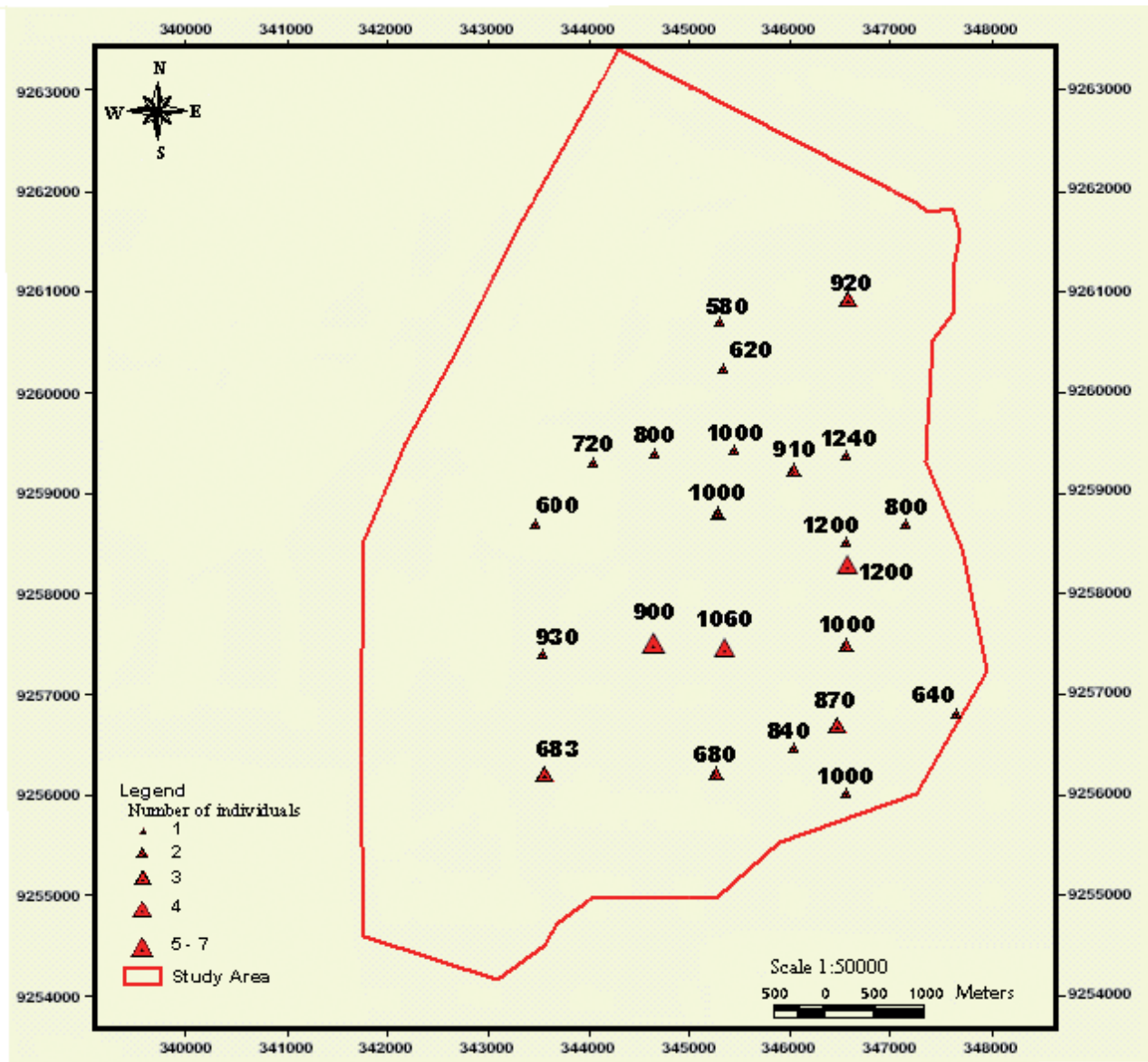

Figure 6. Map of the study area showing the distribution of $P$. angolensis as displayed by the ArcView version 3.2 computer software. Numbers inside the map boundaries show the altitudes while triangles represent plots where $P$. angolensis was recorded.

record $P$. angolensis from the northern, western or southern parts of the reserve. Moreover, the range at which $P$. angolensis occurred in NFR was between 600 to $1240 \mathrm{~m}$ a.s.l. The absence of $P$. angolensis especially in the northern, western and southern parts of the reserve perhaps was a result of selective logging, fires or edaphic factors. The eastern part of NFR consists of steep slopes and difficult terrain. This could be a reason why mature $P$. angolensis were recorded just close to the boundary of the eastern part of the reserve-perhaps tree loggers might be experiencing difficulties in accessing this area. According to Lovett et al. [26], the edges of NFR face fire incidences, deforestation for charcoal making and tree cutting for timber sawing. The villagers at Mkundi and Lukobe also disclosed that people prefer poaching trees for charcoal making and timber just a few hundreds of meters from the edges of the reserve in fear of the forest officers who usually conduct ambush patrols (Personal Communication). Therefore, tree cutting and frequent fires in the edge of NFR are probably the root of mortality 
and poor re-establishment of $P$. angolensis in the northern, western and southern parts of the reserve. Although $P$. angolensis is considered to be resistant to fires, heavy and/or frequent fires damage seedlings and prevent them passing to sapling stages [47].

\section{Implications of the results on carbon management}

The information we have provided in this chapter is expected to guide the authority responsible in overseeing NFR on managing carbon in the forest. Specifically, implementation of the recommendations on fire control and halt of tree cutting highlighted later is necessary to allow for tree restoration, hence increased capacity of the forest in capturing carbon. Awareness raising campaign on biodiversity conservation also insisted later under the recommendations section is essential on deviating the interest of the surrounding communities from overdependence on the forest's biodiversity - to allow the forest to regenerate and augment its capacity in seizing carbon.

\section{Conclusion and recommendations}

This study concludes that the population structure of the common woody species in NFR did not show a natural stand. Fires and selective logging seemed to influence the distribution of timber trees as our model timber species that is, $P$. angolensis was not found in fire prone part of the reserve and the species was as well recorded mostly in hard to reach places. Of the 10 common woody species on the other hand, B. microphylla can be regarded as a foundation species in NFR and its removal should be regulated as when it disappears for example, the ecosystem functioning and the carbon accumulation potential of the reserve might be jeopardized. To manage the tree species sustainably in NFR, this study recommends awareness education on forest biodiversity conservation among surrounding local communities. Regular patrol in the reserve is also needed to stop illegal logging. Fire control is needed to allow for regeneration of the vegetation in the reserve and to minimize seed mortality in order to attain maximum recruitment of the tree species. A study to compare dry and wet season status is required in order to explore the species in its full life cycle as this will take care of the individuals that might be overlooked during dry seasons while in their underground shoot-die back stages. A study to investigate if edaphic factors apart from fires and human disturbances do influence the distribution of the preferred timber species that is, $P$. angolensis is also recommended. Finally, we recommend an exploration of the ecotourism potential of NFR to be undertaken. This might stimulate ecotourism activities in the reserve to provide an alternative source of income and generate jobs among the local population. This would add value and sense of ownership and stimulate self-mobilization among the surrounding communities for protection of the reserve.

\section{Acknowledgements}

The Research Programme on Sustainable Use of Dryland Biodiversity (RPSUD) funded this study. Mr. S. Shomari helped during fieldwork and collection of plant specimen. 


\section{Conflict of interest}

The authors declare no conflict of interest for publication of this study.

\section{Author details}

Robert Modest Byamungu ${ }^{1 *}$, Sayuni B. Mariki ${ }^{1}$ and Nickson Peter Mkiramweni ${ }^{2}$

*Address all correspondence to: robertbmodest@yahoo.com

1 Department of Wildlife Management, Sokoine University of Agriculture, Morogoro, Tanzania

2 Department of Tourism and Recreation, Sokoine University of Agriculture, Morogoro, Tanzania

\section{References}

[1] Ahrends A, Burgess ND, Milledge SAH, Bulling MT, Fisher B, Smart JCR, Clarke GP, Mhoro BE, Lewis SL. Predictable waves of sequential forest degradation and biodiversity loss spreading from an African city. Proceedings of the National Academy of Sciences of the United States of America. 2010;107:14556-14561

[2] Blockhus JM, Dillinbeck MR, Sayer JA, Wegge P, editors. Conserving biological diversity in managed tropical forests. In: Proceeding of a Workshop Held at the IUCN General Assembly, Nov 30-Dec 1, 1990, Perth Australia. Cambridge, UK: IUCN; 1992

[3] Morris RJ. Anthropogenic impacts on tropical forest biodiversity: A network structure and ecosystem functioning perspective. Philosophical Transactions of the Royal Society of London. Series B Biological Sciences. 2010;365:3709-3718

[4] Woods P. Effects of logging, drought, and fire on structure and composition of tropical forests in Sabah, Malaysia. Biotropica. 1989;21(4):290-298

[5] Hough JL. Why burn the bush? Social approaches to bush-fire management in West African national parks. Biological Conservation. 1993;65(1):23-28

[6] Laris P. Burning the seasonal mosaic: Preventative burning strategies in the wooded Savanna of southern Mali. Human Ecology. 2002;30(2):155-186

[7] Laurance WF. Slow burn: The insidious effects of surface fires on tropical forests. Trends in Ecology \& Evolution. 2003;18(5):209-212

[8] Asbjornsen H, Velázquez-Rosas N, García-Soriano R, Gallardo-Hernández C. Deep ground fires cause massive above- and below-ground biomass losses in tropical montane cloud forests in Oaxaca, Mexico. Journal of Tropical Ecology. 2005;21(4):427-434 
[9] Veldmana JW, Mostacedo B, Peña-Claros M, Putz FE. Selective logging and fire as drivers of alien grass invasion in a Bolivian tropical dry forest. Forest Ecology and Management. 2009;258(7):1643-1649

[10] Hines DA, Eckman K. Indigenous Multipurpose Trees of Tanzania: Uses and Economic Benefits for People. Ottawa: Cultural Survival Canada; 1993

[11] Campbell B, Frost P, Byron N. Miombo Woodlands and their use: Overview and key issues. In: Campbell B. editor. The Miombo in Transition: Woodlands and Welfare in Africa. Bogor, Indonesia: CIFOR; 1996. pp. 1-10

[12] Obunga R. Sustainable development of woodcraft industry in Kenya. Technical Progress Report. Nairobi: National Museums of Kenya; 1995

[13] Munyanziza E, Wiersum KF. Indigenous Knowledge of Miombo Trees in Morogoro, Tan zania. Indigenous Knowledge and Development Monitor [Internet]. Vol. 7(2). 1999. Avail able from: https://app.iss.nl/ikdm/ikdm/ikdm/7-2/index.html [Accessed: July 10, 2017]

[14] Modest RB, Maganga SLS, Hassan SN, Mariki SB, Muganda M. Population structure and exploitation of three commercial tree species in Nguru ya Ndege Forest reserve, Morogoro-Tanzania. EJESM. 2010;3(3):41-48

[15] Dallu AIM. Tropical secondary forest management in Africa: Reality and perspectivesTanzania country paper for the FAO/EC LNV/GTZ. In: In Collaboration with ICRAF and CIFOR. Workshop on Tropical Secondary Forest Management in Africa, December 9-13, 2002; Nairobi, Kenya; 2002

[16] Caro TM, Sungula M, Schwartz MW, Bella EM. Recruitment of Pterocarpus angolensis in the wild. Forest Ecology and Management. 2005;219(2-3):169-175

[17] Shackleton CM. Growth patterns of Pterocarpus angolensis in savannas of the south African Lowveld. Forest Ecology and Management. 2002;166(1-3):85-97

[18] Schwartz MW, Caro TM, Banda-Sakala T. Assessing the sustainability of harvest of Pterocarpus angolensis in Rukwa region, Tanzania. Forest Ecology and Management. 2002;170(1-3):259-269

[19] Jew EKK, Dougill AJ, Sallu SM, O'Connell J, Benton TG. Miombo woodland under threat: Consequences for tree diversity and carbon storage. Forest Ecology and Management. 2016;361:144-153

[20] Gatti RC, Castaldi S, Lindsell JA, Coomes DA, Marchetti M, Maesano Paola AD, Paparella F, Valentin R. The impact of selective logging and clear cutting on forest structure, tree diversity and above-ground biomass of African tropical forests. Ecological Research. 2015;30:119-132

[21] Burivalova Z, Sekercioglu C, Koh LP. Thresholds of logging intensity to maintain tropical forest biodiversity. Current Biology. 2014;24:1-6

[22] Magrach A, Senior RA, Rogers A, Nurdin D, Benedick S, Laurance WF, Santamaria L, Edwards DP. Selective logging in tropical forests decreases the robustness of liana-tree 
interaction networks to the loss of host tree species. Proceedings of the Royal Society of London-Series B: Biological Sciences. 2016;283:20153008

[23] Ahrends A. Patterns of Degradation in Lowland Coastal Forests in Coast Region, Tanzania [thesis]. Germany: University of Greifswald; 2005

[24] Pfeifer M, Burgess ND, Swetnam RD, Platts PJ, Willcock S, Marchant R. Protected areas: Mixed success in conserving East Africa's Evergreen forests. PLoS One. 2012;7(6):e39337

[25] CELP. The management and Ecology of Tanzanian Forests. The Environment Department [Internet]. UK: University of York. 2003. Available from: http://www.york. ac.uk/res/celp/index.htm [Accessed: March 26, 2005]

[26] Lovett JC, Fjeldså J, Svendsen JO. Background information on the Uluguru Forests. In: Svendsen JO and Hansen LA, editors. Report on the Uluguru Biodiversity Survey 1993. Sandy: The Royal Society for the Protection of Birds. Danish Centre for Tropical Biodiversity and Tanzania Forestry Research Institute [Internet]; 1995. Available from: http://www.academia.edu/10213590/Report_on_The_Uluguru_Biodiversity_ Survey_1993._Part_A [Accessed: March 14, 2005]

[27] Gerwing J. Degradation of forests through logging and fire in the eastern Brazilian Amazon. Forest Ecology and Management. 2002;157(1-3):131-141

[28] de Steven D. Tropical tree seedling dynamics: Recruitment patterns and their population consequences for three canopy species in Panama. Journal of Tropical Ecology. 2009;10(3):369-383

[29] Kent M, Coker P. Vegetation Description and Analysis. A Practical Approach. 1st ed. New York: Wiley; 1995. 384 p

[30] NTSP (National Tree Seed Programme in Tanzania). Handling Seed of Pterocarpus angolensis (Muninga). Seed Issue Note No. (7). Dar es Salaam: National Tree Seed Programme; 1995

[31] Mueller-Dombois D, Hellenberg H. Aims and Methods in Vegetation Ecology. New York: John Wiley Sons; 1974.547 p

[32] Kershaw KA. Quantitative and Dynamic Plant Ecology. 2nd ed. London: Edwards Anorld; 1974. 308p

[33] Cunningham AB. Applied Ethnobotany: People Wild Plants Use and Conservation. 1st ed. UK: Routledge; $2001.320 \mathrm{p}$

[34] Omeja P, Obua J, Cunningham AB. Regeneration, density and size class distribution of tree species used for drum making in Central Uganda. African Journal of Ecology. 2004;42(2):129-136

[35] Jones L. The spatial distribution of Balanites aegyptiaca (L.) Del. In western Serengeti Tanzania as influenced by edaphic factors [thesis]. Ethiopia: Addis Ababa University; 2004 
[36] Shibru S, Balcha G. Composition, structure and regeneration status of woody species in Dindin natural forest, Southeast Ethiopia: An implication for conservation. Ethiopian Journal of Biological Sciences. 2004;3(1):15-35

[37] Luoga EJ, Witkowski ETF, Kevin B. Regeneration by coppicing (re-sprouting) of miombo (African savannas) trees in relation to land use. Forest Ecology and Management. 2004;189:23-35

[38] Martin GJ. Ethonobotany. A Method Manual. UK: Earthscan; 1995. 268p

[39] Wells J, Wall D. Sustainability of sawn timber supply in Tanzania. International Forestry Review. 2005;7(4):332-341

[40] Newton AC. The Sustainability of uses of trees. In: Report to IUCN. A Contribution to the WCMC/SSC Conservation and Sustainable Management of Trees project; 1996

[41] Dayton PK. Toward an understanding of community resilience and the potential effects of enrichments to the benthos at McMurdo Sound, Antarctica. In: Parker BC, editor. In: Proceedings of the Colloquium on Conservation Problems in Antarctica [Internet]. Lawrence, KS: Allen Press; 1972. Available from: http://daytonlab.ucsd.edu/Publications/ Pubs.htm [Accessed: July 17, 2017]

[42] Ellison AM, Bank MS, Clinton BD, Colburn EA, Elliott K, Ford CR, Foster DR, Kloeppel BD, Knoepp JD, Lovett GM, Mohan J, Orwig DA, Rodenhouse NL, Sobczak WV, Stinson KA, Stone JK, Swan CM, Thompson J, Von Holle B, Webster JR. Loss of foundation species: Consequences for the structure and dynamics of forested ecosystems. Frontiers in Ecology and the Environment. 2005;3(9):479-486

[43] Govorushko SM. Natural Processes and Human Impacts: Interactions between Humanity and the Environment. New York \& London: Springer; 2012. 657 p

[44] Zegeye H, Teketay D, Kelbessa E. Diversity, regeneration status and socio-economic importance of the vegetation in the islands of Lake Ziway, south-Central Ethiopia. Flora. 2006;201(6):483-498

[45] Kacholi DS. Analysis of structure and diversity of the Kilengwe Forest in the Morogoro Region, Tanzania. International Journal of Biodiversity. 2014;2014:8p. Article ID: 516840

[46] van Daalen CJ. Germination of Pterocarpus angolensis seed. SA Fruit Journal. 1991;158: 33-36

[47] Vermeulen WJ. A Monograph on Pterocarpus angolensis. Pretoria: Southern African Regional Commission for the Conservation and Utilisation of the Soil (SARCCUS); 1990. $133 \mathrm{p}$ 
